\title{
Catastrophic necrotizing fasciitis after blunt abdominal trauma with delayed recognition of the coecal rupture - case report
}

\author{
Vanja Pecic, M.D., ${ }^{1}$ Milica Nestorovic, M.D., ${ }^{1}$ Predrag Kovacevic, M.D., ${ }^{2}$ \\ Dragan Tasic, M.D., ${ }^{1}$ Goran Stanojevic, M.D. ${ }^{1}$
}

${ }^{1}$ Clinic for General Surgery, Clinical Center Nis, Nis, Serbia;

${ }^{2}$ Clinic for Plastic and Reconstructive Surgery, Clinical Center Nis, Nis, Serbia

\begin{abstract}
Necrotizing fasciitis (NF) is a rare bacterial infection with dramatic course, characterized by widespread necrosis of the skin, subcutaneous tissue, and superficial fascia which can often lead to death. We present a case of a 27-year-old male with NF. One day after experiencing blunt abdominal trauma caused by falling over bike handlebars, the patient was admitted to a regional hospital and treated for diffuse abdominal pain and large hematoma of the anterior abdominal wall. Due to worsening of general condition, he was referred to our hospital the following day and operated on urgently. Surgery revealed rupture of the coecum with peritonitis and abdominal wall infection. After surgery, fulminant necrotizing fasciitis developed. Antibiotics were prescribed according to wound cultures and subsequent necrectomies were performed.After 25 days, reconstruction of the abdominal wall with skin grafts was obtained. Despite all resuscitation measures including fluids, blood transfusions, and parenteral nutrition, lung infection and MODS caused death 42 days after initial operation. Blunt abdominal trauma can cause the rupture of intestine, and if early signs of peritoneal irritation should present, emergency laparotomy should be performed. Disastrous complication are rare but lethal.
\end{abstract}

Key words: Blunt abdominal trauma; necrotizing fasciitis.

\section{INTRODUCTION}

According to available data, intestinal injuries occur in 5-15\% of blunt abdominal trauma. ${ }^{[I]}$ Early detection and proper surgical treatment are crucially important. Most authors suggest exteriorization of injured intestine. ${ }^{[2-5]}$

Necrotizing fasciitis (NF) is a rare, potentially lethal bacterial infection characterized by widespread necrosis of the skin, subcutaneous tissue, and superficial fascia. ${ }^{[6,7]}$ It develops from a bacterial infection, most often group A Streptococcus (GAS). However, mixed aerobic and anaerobic Gram posi-

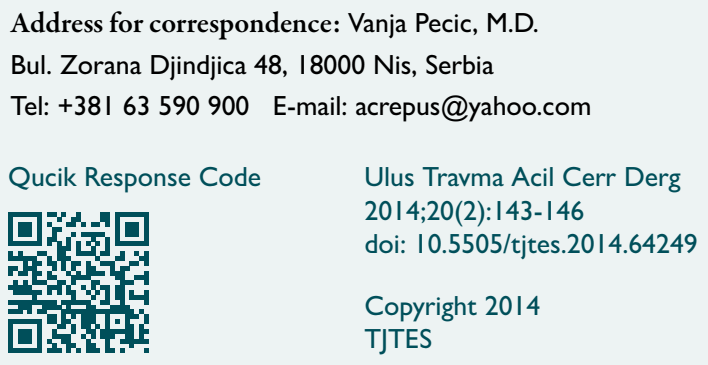

tive (G+) and Gram negative (G-) flora can also be identified. Bad local environment (local tissue hypoxia, depleted leucocytes function) allows the infection to spread much easier, particularly in patients with risk factors such as: medical compromise (e.g., systemic illnesses, immunosuppressive medications), trauma, recent surgery, recent birth, diabetes mellitus, vascular insufficiency, renal and hepatic failure, cancer, or organ transplants. ${ }^{\left[{ }^{8]}\right.}$ Early recognition and proper diagnosis of NF greatly increases a patient's chance of survival. Descriptive terms vary based on the location, depth, and extent of infection (e.g., Fournier's gangrene [necrotizing perineal infection], necrotizing fasciitis [deep subcutaneous infection]). Depending on the depth of invasion, necrotizing soft tissue infections can cause extensive local tissue destruction, tissue necrosis, systemic toxicity, and even death. Despite surgical advances and introduction of antibiotics, reported mortality rates for NF range from 6-76\%. ${ }^{[9]}$ Very often, patients with NF initially go to primary care physicians. Because of the importance of early diagnosis and treatment, primary care physicians need to maintain high index of suspicion for these infections and should be aware of possible presenting features. ${ }^{[9]}$ 


\section{CASE REPORT}

A 27-year-old man was admitted to our hospital one day after the injury obtained by falling over the handlebar of a bike and hitting a lower part of the abdomen. After the injury, he was admitted to a local hospital with symptoms of abdominal tenderness and large haematoma on the right side of anterior abdominal wall. Abdominal ultrasonography did not show signs of free fluid in peritoneal cavity or intraabdominal injury, and plain abdominal and chest $X$-rays did not show irregularities. At admission, the patient's blood pressure was $120 / 80 \mathrm{mmHg}$, heart rate 120/min, WBC 1900/l, PLT 76000/l, Hgb $13 \mathrm{lg} / \mathrm{l}$, Hct $0.4 \mathrm{I}$. After initial resuscitation with $2000 \mathrm{ml}$ Ringer lactate, urine output was low at $200 \mathrm{ml}$ in first six hours. Urinary output was stimulated with $80 \mathrm{mg}$ of furosemide. The patient was treated with antibiotics (Metronidazol $0.5 \mathrm{~g} / 8 \mathrm{~h}$ and ceftriaxone $2 \mathrm{~g}$ ). Twelve hours after admission, his platelet count fell to $55000 / \mathrm{l}$, Hgb to $84 \mathrm{~g} / \mathrm{l}$, Hct to 0.27 . Repeated abdominal X-ray after 12 hours showed presence of discrete free air in abdomen; repeated ultrasonograpy showed free fluid in ileoceecal region which was confirmed by computerized tomography. Due to new diagnostic findings, worsening of general condition, pancytopenia, and spread of abdominal wall muscle haematoma followed by diffuse abdominal muscle resistance, the patient was referred to our hospital. He was admitted to ICU 24 hours after the injury.

An emergency operation was performed upon admittance. Intraoperative findings included the rupture of ileocoecal junction (destruction of Bauchini valve) with consequent diffuse stercoral peritonitis as well as anterior abdominal wall phlegmona. Right hemicolectomy with Brooke ileostomy was performed, followed by wide skin incisions and necrectomy of the anterior abdominal wall. The surgery was terminated with drainage of right retroperitoneal space and abdominal cavity. Postoperatively, blood pressure was $90 / 60 \mathrm{mmHg}$; heart rate was 90/min; WBC was I,200/l; PLT was 50,000; urea was $18 \mathrm{mmol} / \mathrm{l}$ (normal range 2.5-8.3); creatinine was $189 \mathrm{umol} / \mathrm{l}$ (normal range 53-II5); body temperature was $37.6^{\circ} \mathrm{C}$; CRP was 542 (0-5); CPK was 3104 (24-195); procalcitonin was 126.2 (normal range $<0.05$ ). The patient was given antibiotics according to wound cultures and low molecular weight heparin as well as substitution of platelets. Over the next four days, general condition worsened due to the spread of infection on the right side of chest wall and right femoral region (Figure Ia). The patient's body temperature was $38^{\circ} \mathrm{C}$; PLT was 7000-1000; urea was 24; creatinine was 161; WBC was 6500; D-dimer was 5800. Six more units of platelets were added. On the eighth postoperative day, a necrectomy of the left lumbar region and scrotal region was performed. His general condition slightly improved: PLT-33000, CRP-I I 2. On several occasions wounds were aggressively debrided under general anaesthesia (Figure Ib).Twenty days after operation, the abdominal wall skin defect was reconstructed with partial thickness skin grafts (Figure Ic). The patient's vital
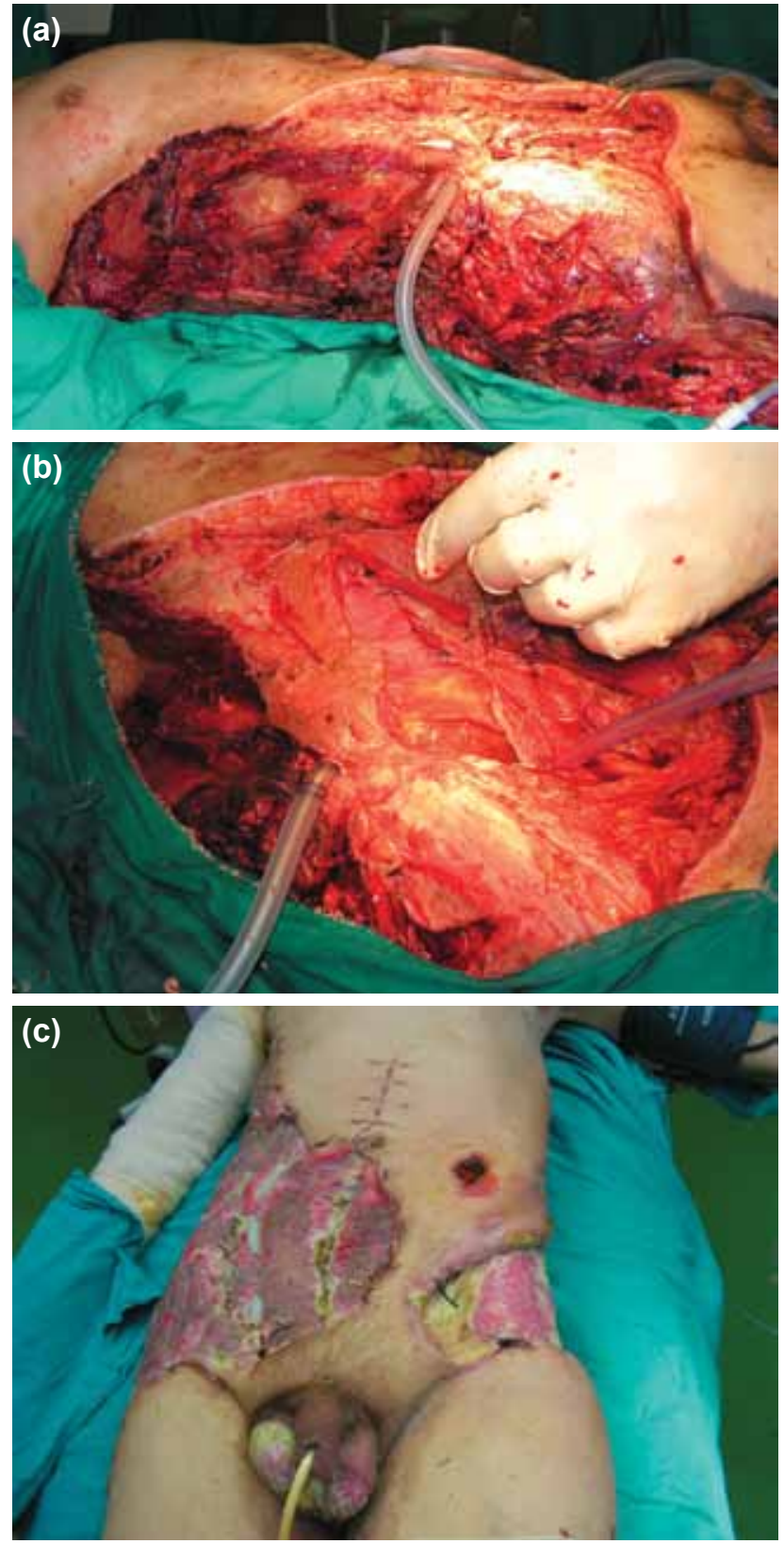

Figure 1. (a) Spreading of infection to the chest wall and femoral region. (b) Debridement of the wound. (c) Reconstruction of the abdominal wall with skin grafts.

signs were stable and body temperature was (BT) $38.4^{\circ} \mathrm{C}$. Over the next eight days, his vitals were stable $\left(B T 38^{\circ} \mathrm{C}\right.$, urine output $2700 \mathrm{ml} / 24 \mathrm{~h}$, PLT 68000) and the skin graft was mostly accepted. After 34 days, his condition got suddenly worse. He developed acute renal failure (with elevated blood urea nitrogen and creatinine), liver failure, and respiratory insufficiency requiring artificial respiration. He was intensively reanimated. Forty-two days after operation, the patient died.

\section{DISCUSSION}

Blunt abdominal trauma (BAT) is common, and the prevalence of intra-abdominal injury (IAI) after BAT has been reported 
to be as high as $12-15 \% .{ }^{[10]}$ Diagnostic evaluation of patients with BAT include physical examination, focused ultrasonography, computed tomography (CT), diagnostic peritoneal lavage, laparoscopy, laparotomy, laboratory tests, and observation. Patients who have sustained BAT and have undergone otherwise negative diagnostic evaluation in the emergency department (ED) will also undergo CT of the abdomen and pelvis, admission to the hospital for an extended observation period, or both, in order to be evaluated for occult IAI. ${ }^{[10,11]}$ However, the incidence of IAI in patients who are otherwise hemodynamically stable and have initially negative diagnostic evaluations in the ED is quite low, probably occurring in less than $1 \%{ }^{\left[{ }^{1 I}\right]}$

The frequency of NF is about 0.40 cases per 100.000 and is correlated with inadequate oxygenation and nutrition of tissue. The course of NF varies and is often deceitful. The cardinal early symptom is a disproportionately strong pain in comparison to patient's examination. The beginning ailment may suggest many other conditions, e.g., cellulitis, erysipelas, phlebitis, etc. It is known that $35 \%$ of patients with NF are initially misdiagnosed. ${ }^{[7]}$

New and stronger antibiotics have been introduced over the last 30 years and, together with improved critical care and surgical techniques, have considerably changed the outcome of patients with sepsis. Source control is generally considered to be an important element in the management of these patients. The importance of "early" in the management of severe sepsis has gained much attention in the last few years. Intense research for biomarkers has been performed to help clinicians to diagnose infection early in the course of the disease. Regarding IAI, source control is often defined as the pure mechanical control of leaking content from the gastrointestinal (Gl) tract. Surgeons often intuitively feel that source control is a part of a surgical intervention; however, the opposite is true: surgical intervention is part of a source control approach to the patient with IAI. ${ }^{[12]}$

In some patients, tissue necrosis can rapidly advance, and "time is tissue:" hourly progression of soft tissue necrosis can be seen even after initiation of antibiotics. Boyer et al. ${ }^{[13]}$ demonstrated that in patients in septic shock, surgery postponed for more than 14 hours after diagnosis increases the risk of mortality by a factor of 34 . In our case, postponing surgery for more than 24 hours contributed further to the patient's morbidity and possible mortality.

After source control and treatment of infection, early closure of the wound is not recommended due to the risk of residual bacteria and poor wound healing. According to some authors, debridement and dressing changes are the method of choice for wound management, with slow granulation and muscle and skin grafting. ${ }^{[14]}$

Skin and muscle grafts may be used only after the infection is cleared. In a study of 60 patients, Salcido ${ }^{[15]}$ used skin and rotational flaps in approximately $48 \%$ and $5 \%$ of cases, respectively.

Other treatments for NF include VAC (Vacuum Assisted Closure) or hyperbaric oxygen therapy (HBO). VAC (VAC; Kinetic Concepts, Inc., San Antonio, TX) is a wound care system that works on the basis of negative pressure vacuuming to regulate the wound pressure, reduce edema, eliminate fluid collections, decrease bacterial contamination and promote healing. ${ }^{[16]}$ VAC was introduced by Fleischmann et al 1995 and Morykwas et al in 1997 and gained popularity among clinicians who started to use it for the treatment of chronic wounds. The VAC therapy has proved very useful in acute/chronic wounds treatment, especially in big traumas, diabetic ulcers, and in the poorly-vascularized post-traumatic lesions, but always after surgical debridement of the wound. [16-18] Both patients and physicians are more comfortable with VAC treatment compared to conventional methods; although it does not shorten the length of the hospital stay or the time from initial debridement to closure, it does decrease number of interventions. The main criticism of VAC therapy has been its cost. ${ }^{[16]}$ VAC system was not available at the time of treatment of this particular patient.

Hyperbaric oxygen therapy delivers multiples of atmospheric pressure and is capable of inducing arterial oxygen tensions of up to $2000 \mathrm{mmHg}$. Through this effect, HBO therapy may ameliorate tissue hypoxia induced by microcirculatory thrombosis in a number of ways. Heightened oxygen tension increases phagocytic bactericidal activity and even kills certain anaerobes independent of host immunity. Beyond the initial stages of infection, HBO therapy may also improve wound healing, which could lead to reductions in the number of debridements and amputations necessary in patients with NF. In a recent study conducted by Massey et al, HBO did not reduce mortality or decrease number of amputations in patients with NF. ${ }^{[9]}$ German authors also agree that previously published human clinical studies do not confirm any therapeutic benefit of $\mathrm{HBO}$ in NF patients. Any time delay in the start of surgical therapy is not acceptable. They propose initiation of a register study to assess the benefit of $\mathrm{HBO}$ in NF patients. ${ }^{[20]}$

\section{Conclusion}

Despite the small percent of risk, patient's blunt abdominal trauma should always be considered for intestinal rupture even in cases with initial negative diagnostic evaluations. Unrecognized injuries, especially of hallow viscera, can lead to serious infections like NF. Since NF progresses rapidly, causing destruction of soft tissue, early recognition and management are crucial. Surgical management must be aggressive and meticulous. Source control is considered as essential element in the management of sepsis and should be done promptly after diagnosis. Patients with symptoms of rapidly progressive disease (e.g., necrotizing skin and soft tissue infections) 
or patients with $\mathrm{Gl}$ tract perforation and diffuse peritonitis should be operated on within 1-2 hours after diagnosis. One must always bear in mind that clinical course of infection is unpredictable.

\section{Conflict of interest: None declared.}

\section{REFERENCES}

1. Mukhopadhyay M. Intestinal injury from blunt abdominal trauma: a study of 47 cases. Oman Med J 2009;24:256-9.

2. Sasaki LS, Allaben RD, Golwala R, Mittal VK. Primary repair of colon injuries: a prospective randomized study. J Trauma 1995;39:895-901.

3. Lazović R, Krivokapić $Z$. The role of enterostomy in the management of colonic injuries. [Article in Serbian] Acta Chir Iugosl 2005;52:73-82.

4. Tzovaras G, Hatzitheofilou C. New trends in the management of colonic trauma. Injury 2005;36:1011-5.

5. Brasel KJ, Borgstrom DC, Weigelt JA. Management of penetrating colon trauma: a cost-utility analysis. Surgery 1999;125:471-9.

6. Angoules AG, Kontakis G, Drakoulakis E, Vrentzos G, Granick MS, Giannoudis PV. Necrotising fasciitis of upper and lower limb: a systematic review. Injury 2007;38 Suppl 5:19-26.

7. Hady HR, Mikucka A, Gołaszewski P, Trochimowicz L, Puchalski Z, Dadan J. Fatal necrotizing fasciitis following two suicide attempts with petroleum oil injection. Langenbecks Arch Surg 2011;396:407-13.

8. Smuszkiewicz P, Trojanowska I, Tomczak H. Late diagnosed necrotizing fasciitis as a cause of multiorgan dysfunction syndrome: A case report. Cases J 2008;1:125.

9. Headley AJ. Necrotizing soft tissue infections: a primary care review. Am Fam Physician 2003;68:323-8.

10. Kendall JL, Kestler AM, Whitaker KT, Adkisson MM, Haukoos JS.
Blunt abdominal trauma patients are at very low risk for intra-abdominal injury after emergency department observation. West J Emerg Med 2011;12:496-504.

11. Stephan PJ, McCarley MC, O'Keefe GE, Minei JP. 23-Hour observation solely for identification of missed injuries after trauma: is it justified? J Trauma 2002;53:895-900.

12. De Waele JJ. Early source control in sepsis. Langenbecks Arch Surg 2010;395:489-94.

13. Boyer A, Vargas F, Coste F, Saubusse E, Castaing Y, Gbikpi-Benissan G, et al. Influence of surgical treatment timing on mortality from necrotizing soft tissue infections requiring intensive care management. Intensive Care Med 2009;35:847-53.

14. Cainzos M, Gonzalez-Rodriguez FJ. Necrotizing soft tissue infections. Curr Opin Crit Care 2007;13:433-9.

15. Salcido RS. Necrotizing fasciitis: reviewing the causes and treatment strategies. Adv Skin Wound Care 2007;20:288-95.

16. Ozturk E, Ozguc H, Yilmazlar T. The use of vacuum assisted closure therapy in the management of Fournier's gangrene. Am J Surg 2009;197:660-5.

17. Chiummariello S, Guarro G, Pica A, Alfano C. Evaluation of negative pressure vacuum-assisted system in acute and chronic wounds closure: our experience. G Chir 2012;33:358-62.

18. Thwaini A, Khan A, Malik A, Cherian J, Barua J, Shergill I, et al. Fournier's gangrene and its emergency management. Postgrad Med J 2006;82:516-9.

19. Massey PR, Sakran JV, Mills AM, Sarani B, Aufhauser DD Jr, Sims CA, et al. Hyperbaric oxygen therapy in necrotizing soft tissue infections. J Surg Res 2012;177:146-51.

20. Willy C, Rieger H, Vogt D. Hyperbaric oxygen therapy for necrotizing soft tissue infections: contra. [Article in German] Chirurg 2012;83:96072 .

\section{OLGU SUNUMU - ÖZET}

\section{Künt abdominal travma sonrası katastrofik nekrotizan fasiitle birlikte çökal rüptürün tanınmasında gecikme - olgu sunumu}

\section{Dr. Vanja Pecic,, ${ }^{1}$ Dr. Milica Nestorovic, ${ }^{1}$ Dr. Predrag Kovacevic, ${ }^{2}$ Dr. Dragan Tasic, ${ }^{1}$ Dr. Goran Stanojevic}

${ }^{1}$ Nis Merkez Kliniği, Genel Cerrahi Kliniği, Nis, Sırbistan;

${ }^{2}$ Nis Merkez Kliniği, Plastik ve Rekonstrüktif Cerrahi Kliniği, Nis, Sırbistan

Nekrotizan fasiit (NF) dramatik bir seyir çizen, yaygın deri, deri altı dokusu ve yüzeyel fasyanın nekrozu ile karakterize sıklıkla ölüme yol açabilen ve seyrek görülen bir bakteriyel enfeksiyondur. Bu yazıda, 27 yaşında bir erkek NF olgusu sunuldu. Hasta, künt karın travmasından bir gün sonra bölge hastanesine kabul edildi. Ertesi gün hastanemize sevk edildi ve acilen ameliyat edidi. Önceden yaralanmadan hemen sonra bir bölge hastanesinde yaygın karın ağrııı ve ön karın duvarında geniş bir hematom nedeniyle tedavi edilmişti. Bisiklet sürerken gidonun üzerine düşüp yaralanmıştı. Genel durumun kötüleşmesi üzerine hastanemize sevk edilmişti. Ameliyatta peritonitle ve karın duvarı enfeksiyonuyla birlikte çekum rüptürü saptandı. Ameliyattan sonra fulminan nekrotizan fasiit gelişti. Yara kültürlerine göre antibiyotikler reçetelendirildi. Daha sonra nekrotik dokular alındı ve 25 gün sonra deri greftleriyle karın duvarı rekonstrüksiyonu yapıldı. Sıvılar, kan transfüzyonları ve parenteral beslenme gibi tüm resüsitasyon önlemlerine rağmen akciğer enfeksiyonu ve çoklu organ işlev bozukluğu sendromu (MODS) nedeniyle ilk ameliyattan 42 gün sonra hasta kaybedildi. Künt karın travması intestinal rüptüre neden olabilirdi. Periton iritasyonunun erken belirtilerinde acil laparotomi uygulanmalıdır. Feci komplikasyonlar seyrek görülmesine rağmen ölümle sonuçlanır.

Anahtar sözcükler: Künt karın travması; nekrotizan fasiit.

Ulus Travma Acil Cerr Derg 20।4;20(2):143-146 doi: 10.5505/tjtes.20I4.64249 